\title{
The Roles of Foreign Language in Business Administration
}

\author{
Thavorn Thitthongkam (Corresponding author) \\ School of Management, Shinawatra International University \\ BBD Building, Viphawadi-Rangsit Road, Phaya Thai, Bangkok 10400, Thailand \\ Tel: 66-2-650-6031 Fax: 66-2-650-6033 E-mail: thavorn.th@spu.ac.th \\ John Walsh \\ School of Management, Shinawatra International University \\ BBD Building, Viphawadi-Rangsit Road, Phaya Thai, Bangkok 10400, Thailand \\ Tel: 66-2-650-6031 Fax: 66-2-650-6033 E-mail: jcwalsh@siu.ac.th \\ Chanchai Bunchapattanasakda \\ School of Management, Shinawatra International University \\ BBD Building, Viphawadi-Rangsit Road, Phaya Thai, Bangkok 10400, Thailand \\ Tel: 66-2-650-6031 Fax: 66-2-650-6033E-mail: chanchai@siu.ac.th
}

\begin{abstract}
This paper explores the roles of foreign language in business administration, investigates managerial perspectives and studies the problems of foreign language usage in communication to discover modes of developing employee's foreign language ability and to investigate the students' opinions concerning the roles of foreign languages in business administration in Thailand. In-depth, face-to-face qualitative interviews were employed. The results indicated that foreign languages play significant roles in import and export companies. In the managers' point of view, foreign languages are very important to their businesses, especially for communication with customers, other companies and suppliers. The problems in some companies might happen because of differences between customers. The problems also come from both senders and receivers who lack knowledge of foreign languages. The informants stated that organizations should invite professional trainers to help improve foreign language skills in vocabulary and conversation in particular.
\end{abstract}

Keywords: Business administration, Roles of foreign language, Managerial perspectives, Language communication, Language and culture 


\section{Introduction}

Language is a vital tool that we use to communicate with other people in our daily and working lives (Sanstead, 2001; Adejimola, 2008). It consists of words and meanings that are combined into discrete units (sentences) (Hagoort \& Van Berkum, 2007; Van Berkum, 2008). Sentences joined together become information that can be used to exchange ideas with other people (Lieberman, 2008). Although language is important in working life, linguistic skill in itself is insufficient (Cantoni, 1998; Geneva 2002; Hulstrand, 2008). Foreign languages are also important and play important roles in business administration. In business administration, foreign language plays several roles, such as a role in internal (Marchan et al., 1997; Marschan-Piekkari et al., 1999; Davies, 2000) and external communication (Marchan et al., 1997; Davies, 2000; Leslie \& Russel, 2006), a role in having a chance to get a good job, and a role as a means to understand other cultures. Good communication in foreign language becomes so crucial in today's world (Cole, 1988) owing to the impact of globalization. For global competitors, the most important factor is the ability to communicate on a wider, quicker and clearer basis (Schorr, 2005). Ability in communication is focused on foreign languages which are widely used (Walters, 1990).

The importance of the roles of foreign language in business administration is for communication with customers, competitors, employers, employees and colleagues (GO, 2009). In fact, communication begins early in life as we can see the fact that the baby has a need is communicated by a simple cry (Ruffin, n.d.). As children grow older, the communication process becomes more complex (Stewart, 1985). Communication is very important in the business field in terms of sending messages to receivers or speaking clearly to listeners. Foreign language ability also plays very important roles in business administration in helping increase the opportunities for understanding and in learning other cultures (Griva \& Sivropoulou, 2009).

Understanding the roles of foreign language will be beneficial because it assists understanding of conversations, communications and negotiations between practitioners and foreign customers. Practitioners can run businesses more smoothly with the use of foreign languages (Peh, 2005) and their foreign customers will feel more comfortable. In business administration, not only are speaking and listening skills important but also other skills including reading, writing and negotiating (Stewart, 1973). Language is, seemingly, omnipresent and successful communicators apply principles of human behavior (Stewart, 1973). Any foreign language can be used in business depending on customers and the nature of the business and market involved. Understanding the type of language required and the degree to which understanding of it is required is an important managerial skill.

Aside from advantages for employees, customers can also expect advantage from sophisticated language use. They can obtain the required appropriate products or services. For instance, with the productive foreign language communication, customers get what they order in a wholesale-shop. In contrast, for the unproductive foreign language communication, the customers might face a confusing-problem or do not get what they order. This problem seems small, but it can be the high-risk if it happens too often. Language creates customers' 
satisfaction (Crystal, 1989) which will lead to competitiveness. Competitiveness cannot happen without ability to handle well with customers. Batt (2008) studied the research entitled 'English Skills Gap is Costing Thai Businesses', and it was published in

BusinessWeek Thailand. He pointed out the case had lost business worth upwards of THB17 million (US\$500,000) because of a failure to deal which English language communications from a British business. This indicated that language plays an important role in business administration (Barlas et al., 2002; Batt, 2008; Rasouli, M. et al 2008). Also, foreign language plays a role in assisting customers who face problems in communication (Cotton et al., 2007), especially in terms of communication with multi-national companies and companies outside a country.

Moreover, foreign languages play a role in having more chance to get a good job. Many businesses are looking for people who are fluent in other languages. Foreign language skill provides a competitive edge in career choices in the contemporary job market (Ebling, 2005). Many companies want their new employees to possess foreign language skills and need people with high levels of proficiency. For existing employees, some companies will provide foreign language courses to sharpen their language skills so employees can use them more effectively.

Furthermore, foreign language plays a role as a means to understand other cultures (Voght and Schaub, 1992). Understanding cultures of customers is beneficial in running businesses. The world opens widely to meet people from different cultures and understanding the customer's culture helps organizations manage conflicts arising from cultural barriers or differences.

The purposes of this study are to explore the roles of foreign language in business administration, to investigate managerial perspectives concerning the roles of foreign language, to study the problems of foreign language usage in communication with customers, to discover modes of developing employees' foreign language ability, and to investigate the co-operative education students' opinion concerning the roles of foreign languages in business administration in Thailand.

With these objectives in mind, the paper is structured in three further sections. In the first section, a review of literature serves as a reference for analysis of the results. In the second section, the setting of the research and methodology employed are described. In the third section, there is a presentation of the research findings obtained and the data analyzed in order to answer the research questions. Finally, conclusions are drawn and recommendations are made that will assist in facilitating a business that encourages economic and business development.

\section{Literature Review}

\subsection{What is business?}

The word "business" means the activities of buying and selling of goods or services, the work that we do to earn money, or an organization that sells goods or services (Walter, 2004). 
Business involves advantages, profits, and money. Friedman (1994) defined the word "business" as the commercial enterprise, profession, or trade operated for the purpose of earning a profit by providing a product or service. Businesses are created by entrepreneurs who put money at risk to promote a particular venture for the purpose of a profit. They vary in size from one-person selling to an international corporation having billion of dollars in assets and thousands of employees.

According to Thill (2001), there are a wide variety of career areas that exist in business settings such as, business management, finance, human resources, marketing, sales, public relations, and industries. Business is important. It involves economies because it can earn revenue from both inside and outside of the country. Business can also build good relationships across borders. To succeed in running a business, organizations must share information with people both inside and outside the organization. The reason is that a goal of business is to communicate with others to sell products or to provide services, and to communicate inside the organization to have a good cooperate among the commander and workers (Mendonca, 2003). There are three types of principle forms in business organization: Sole Proprietorship, Partnership and Corporation.

The sole proprietorship is the oldest, most common, and simplest form of business organization. It is a business entity owned and managed by one person. It can be organized very informally which is not subject to much federal or state regulation, and is relatively simple to manage and control (Coleman, 2004; Mauro, 2008). So the sole proprietorship has only one business owner, and is a good business organization for individual who wants to start a small business. The sole proprietorship is beneficial to the country's economy. If a country's economic structure is large enough, the country's economy is hard to collapse, once there is economic crisis.

The second type is the partnership. It is a type of business entity in which partners share with each other the profits or losses of the business undertaking in which all has invested. Thus, partnership is a state of being a partner for sharing the rewards if the business is successful, search information and discuss. Whenever there are problems, a partner can try to help solve them.

The third type of business ownership model is the corporation. Here, the ownership is divided into shares and management distributes net profits in the form of dividends to shareholders. So a corporation is a separate legal entity. The corporation comes into legal existence when its founders comply with their state's incorporation process (Iwai, 2001).

Most definitions of business type concentrate on the activities involved in earning money such as selling of products and services. For the purposes of this study, business involves all types of business forms previously specified.

\subsection{Demand for foreign language competency in business administration}

There is a demand for foreign language competencies in business administration (Dipte \& Ali, 2009). The demand of foreign language in business administration is for communication. In 
sharing information among employees, employers and customers, foreign language plays important role both inside and outside the company (Lechner, 2008).

Foreign language usage inside the company is a form of internal communication that employees need to interact between themselves and with co-workers, and employers. It is important to use the correct grammar, syntax and spelling in order to promote understanding and to maintain the image of the organization. Foreign language usage also helps to build good relationships (Castro, 2006) that promote working processes through encouraging cooperation from employees in every section of the company. Most successful business communication comes from listening and talking (Theobald, 2006).

Foreign language usage outside the company is a form of external communication (Grosse, 2004), such as, for example, when the sales manager deals with the salespeople. They use foreign language as a means of communication for products or services of the organization, to provide information and to persuade customers to purchase products or services. Foreign language usage with customers must be clear enough for them to understand and it should also be positive and friendly so that customers feel positive about using the products or services. For customers, it is very important for them to know and to understand all the details and conditions of products and services so as to make better decisions.

\subsection{Roles of foreign language in business administration}

Nowadays, many businesses have expanded worldwide (Dixuan, 2003). Many investors invest in other countries. Thus, foreign language is necessary (Cook, 2007; Pine, 2006). Foreign language plays a significant role in communicating (Cline, 1998; Stone, 2009) and foreign language opens up different and better opportunities (Mittlesatnds, 2007; New Zealand Herald, 2007; Odlin, 2007). The success of business administration will depend on the quality of information about its customers, its competitors and the market in general.

\subsection{Foreign language roles in internal communication}

People who work in an organization need to talk to each other to make others know what they want or what they need. They sometimes want to share their thoughts and to listen to others (Cong, 2007). Foreign language can be a means to help them understand each other. If nobody communicates within an organization, there are likely to be problems. Lack of communication will cause working process problems. Communication can be a way to build a good relationship between employees inside an organization (Mark, 2007). In fact, the roles of language in internal communication and external communication will support each other. If the internal communication works well, the external communication can work effectively too (Grunig 1992). Internal communication involves all forms of communication that exists within an organization. Communication may be oral, written, face-to-face, virtual or in groups. Internal communication helps to establish formal roles and responsibilities for employees and lead to the success of an organization.

\subsection{Foreign language roles in external communication}


The roles of language in external communication will involve speaking face-to-face with the customers (Samova \& Porter, 2004). It can also be a written message like some quotes from an important or even legendary person or a billboard advertisement. From these messages, customers develop an understanding about the company (Stewart et al., 2005). This shows how important are language roles in external communication that can gain profits for organizations. An organization will get more customers from the messages and actions that express what the organization truly is. It reveals many things to customers and the wider community. Just as internal communication carries information up, down, and across the organization, external communication carries it into and out of the organization (Thill, 2005).

\subsection{Foreign language roles and customer satisfaction}

The roles of language in business administration and customer satisfaction are both related in business. Customer satisfaction depends on what and how the customers gain from the organization after an interaction. Both verbal and non-verbal forms of communication are important in this regard. Communication skills will be used as a first step to reach customers and make them satisfied with the organization's offerings. The more that customers are satisfied, the more the organization gains advantages. Foreign language plays an important role in making customers feel comfortable about buying products or services (Runnakit, 2007). The company needs to use positive and friendly language to show understanding and care for their customers. Listening to customers carefully to know what they need or want from the organization is very important, because it makes the company staff know how to make them satisfy. Consequently, the company can offer them some form of promotion and for products that are directly related to their needs.

Moreover, the company will need to show the same level of care and attention in looking after their customers as well as the first time the company staff meet the customers. This is called after-sales service which should impress customers and will build loyalty to the organization in their minds. For example, mobile phone call centres answer any questions from customers and so need to use a form of speaking that includes concision, completeness, effectiveness and positivity to help customers understand the answers and to feel good and satisfied with the service received.

\subsection{Language and culture}

Language and culture cannot be separated and are in fact part of each other (Jenkins, 2000). Culture has a component that consists of words. Attempting to communicate meaning through the transmission of a message to someone from a different cultural background runs into the danger that cultural differences will lead to misunderstanding (Robock, 1989).

Understanding language and using it perfectly requires understanding its cultural component too. To clarify, some words with the same meaning can be used in different situations or some words can be very rude in some other languages. One example of this is the word "pumpkin" in English, which is "fuktong" in Thai, which clearly can cause some offence. Culture involves learning and sharing forms of behaviour, norms, values and material objects (Stoyko, 2009). It also encompasses what people create to express values, attitudes and norms. 
Communication systems such as language and nonverbal communication are products of culture. Cultural misunderstandings in business activities can be destructive to an organization. Mistakes can be unconscious as well as unintentional (Varner, 2005).

\section{Methodology}

The objectives of this study were to explore the roles of foreign language in business administration, to investigate managerial perspectives concerning the roles of foreign language, to study the problems of foreign language usage in communication with customers and to discover modes of developing employees' foreign language ability in business administration in Thailand.

This study was based on in-depth, face-to-face qualitative interviews with a convenience sample of 53 managers. The managers were from different companies and departments and represented all types of business form. There were 30 tour company managers, 15 hotel managers, 3 import and export company managers, 3 jewelry store managers, a transportation company manager and a telecommunications company manager. They were selected on a random basis within Bangkok, the capital city of Thailand. There were additional interviews conducted with 53 co-operative education students. The aims were to explore the roles of foreign language in business, to investigate the manager perspectives concerning the roles of foreign language, to study the problems of foreign language usage in communication with customers, to discover modes of developing employees' foreign language ability and to investigate co-operative education students' opinions concerning the roles of foreign language in business administration in Thailand.

A set of the interview guidelines in English was created as a research instrument by the researchers. The interview guidelines consisted of two main parts. The first part was designed to obtain the interviewee's personal information (e.g. gender, educational background, years of working experience, type of business, etc.) and the second part consisted of questions related to the objectives of the study as identified above.

After designing the set of interview guidelines, they were given to experts in designing such guidelines for their consideration. The aim was to determine whether wordings, questions and question order issues contained in the guidelines were clear to the interviewees and, as a result, some minor adjustments were made.

Interviews were arranged beforehand Formal letters requesting an interview were also prepared on request. Appointments with managers were made about two weeks in advance. Interview guidelines were sent to managers in advance by e-mail and fax so that respondents had time to prepare answers.

Interviews were conducted in company offices when the researchers went to observe the co-operative education students. Sometimes interviewing was conducted in offices, coffee shops, restaurants, hotels and elsewhere. The interviewing time lasted approximately 25-35 minutes. Fifty three cooperative education students were interviewed after they had experienced four months of business administration studies. 
There are limitations to this study. First, the respondents in the sample were from diverse businesses and, second, the time was quite limited. In the future, more specific business or industry sectors should be selected and more time should be considered. Moreover, the interviewing guidelines should be developed by adding more question areas for better results.

This paper presents only some of the findings, which are those concentrating on roles of foreign language in business administration, managerial perspectives concerning the foreign language, the problems of foreign language usage in communication with customers, modes of developing employees' foreign language ability and the co-operative education students' opinion concerning the roles of foreign language in business administration in Thailand.

\section{Research Findings}

The research findings are divided into five sections: (1) the roles of foreign language in business administration, (2) managerial perspectives concerning the roles of foreign language, (3) the problems of foreign language usage in communication with customers, (4) modes of developing employees' foreign language ability, and (5) the cooperative education students' opinions concerning the roles of foreign language in business administration in Thailand.

\subsection{Foreign language in business administration}

From the interviews, it became apparent that foreign languages are significant in business administration. The kinds of businesses in which foreign languages play significant roles in particular are in import and export companies concerning agricultural products such as rice, rubber, tropical-fruits, crops, handicrafts, local-products, gems and seafood. This sector is known as being one offering major income for Thailand because of the presence there of various natural-resources. Furthermore, these companies help improve the quality of life for many Thais. In the many forms of communication used here, that dealing with negotiations is prominent. It is necessary for the import and export businesses to be able to negotiate with their partners in trading, because they have to gain benefit from any deal while retaining good relationships for future interactions.

In addition, Thailand needs to import a large number of products which cannot be produced efficiently in the domestic economy. It is currently unable to produce some kinds of product which may need special inputs, such as high-technology parts for computers, medical equipment, cosmetics and chemicals. As Thailand is unable to produce them on its own, it is necessary for Thailand to communicate with foreign suppliers to obtain them and so of course communication is important.

Hotels and tourism represent a major source of income for Thailand. Consequently, effective communications are significant for sending messages to customers and intermediaries. Some tourism destinations in the country are world famous, including Chiang-Mai, Phuket, Krabi, Samui and Pattaya. Foreign languages are used in promotions, invitations and service provision, as respondents explained.

Also, foreign languages are important in making a first-impression with tourists. Often, with backpackers, the offers concerning accommodation are in foreign languages. As a result of a 
good first impression, international tourists and visitors will probably come back again to visit the country.

\subsection{Managerial perspectives concerning the roles of foreign language}

Foreign language skill from the managers' point of view is very important to their business administration, especially for communication with customers, other companies, suppliers and other stakeholders. Informants stated that communication gave the opportunity to expand their businesses from the national level to the international level, which offers further success. All the informants that the researchers interviewed have Thai people as a part of their major customers and many of the materials that are needed in their business are ordered from foreign countries. They import jewelry from India, for example. Knowledge of foreign languages is a must in this case and they have to communicate at least in English to negotiate or to make a contract to get needed materials for their business processes.

Communication with customers is as important as communication with suppliers or other organizational networks, because customers both local and foreign are the main factor in determining the profits and benefits available for the business. To achieve the goal in every business, informants indicated that they needed to make customers satisfied and loyal to their businesses or organization so that customers will use products or services again. Customer satisfaction with products or services is important in making customers feel comfortable and secure. The informants also expressed the view that customers might forward their feelings of loyalty to their friends and connections through word of mouth and this is another advantage for the businesses. However, serving customers with the best service may not enough. Managers and all members of the business need to know the arts of communication to deal with different kinds of customers and this includes knowledge of foreign languages.

Finally, the informants from the sample indicated that foreign languages are important because they play an important role in competing with competitors. Foreign language competency can enable the company to operate in the international market while serving customers in their own language. In other words, it appears to be a means of achieving localisation and this is very important in many product sectors.

\subsection{The problems of foreign language usage in communication with the customers}

The researchers found that some problems occurred because of differences between customers. Not all foreign customers can communicate in a foreign language, whether or not it is English. Many could speak only their own language, whether it is Russian, Italian, French or Danish. They could not speak English very well and sent in orders in very bad English in terms of grammar and spelling mistakes. This situation often occurred for transportation companies. The issue for the company was to guess the meaning from the context from incorrect sentences and to use clear and easy English that those customers might be able to understand. This opens the possibility of errors in the communication channel that come from senders and receiver who do not understand each other. In such a case, the problem concerns the need for the partners to adapt themselves to understand and respond to the order correctly, as well as other forms of interaction. 
Obviously, the problems came from both senders and receivers who lacked knowledge of the foreign language. In this situation, it was shown that senders might lack knowledge in English and so they used it randomly. In some cases, the receivers did not know any Russian, Italian, French or Danish and so they did not know how to respond to the customers, or were not sure they understood the message in English, because of their lack of knowledge. In this situation, the informants pointed out that they could not blame their customers' language skills because it is not their responsibility to speak a foreign language well. For companies which faced the problem frequently, informants stated that studying other foreign languages was beneficial for them.

4.4 Modes of developing employees' foreign language ability in business administration in Thailand

Others findings involved the mode of developing employees' foreign language ability or skills training for company staff. The informants realized that English is not only important but is necessary for administrating business. They also stated that organizations should invite professional trainers to help improve English skills in vocabulary and conversation. Writing skill for employees is also important, so that employees can complete written tasks such as letters, memos, reports and so forth. They will know whether details are correct or not. The respondents also emphasized that the organization should strongly consider providing support for language skill development.

In terms of communication, foreign language is very important for business administration, so communicators should not make too many mistakes, since these can cause problems and delay business. This example urges managers as respondents to know that communication should be effective from both senders and receivers. The managers who are the leaders of the group need to have a responsibility to use language properly to communicate effectively. It is their duty to speak concisely, clearly and completely to their staff or customers. Conciseness and completeness represent a means to achieve success. If managers do not assign work clearly, the staff might misunderstand the message which might then cause some conflicts between the managers, the staff and the customers. Then, communication at work is not only an issue of knowledge about the foreign language but it also means the managers need to know how to use it properly with respect to different contexts and situations. This will help managers manage and prevent conflicts that can happen at the workplace. Communication at work should be pursued carefully because, in the world of business, if there are any mistakes or misunderstanding during agreeing working conditions or signing contracts, for example, this can lead to expensive and long-lasting problems. In brief, communication at work should involve as few mistakes as possible.

\subsection{Co-operative education students' opinion concerning the roles of foreign language}

Interviews with co-operative education students emphasized the importance of foreign languages because of the number of foreign customers. Informants observed that they must be able to communicate using foreign languages when required. In terms of communication, foreign languages were used to communicate with customers when the informants were on duty all the time. Fluency in foreign languages made for satisfied customers. To co-operative 
education students, foreign languages were also used for internal communication. It occurred when they cooperated with foreign administrators, managers, employers and other foreign employees.

Informants further pointed out that foreign languages played roles as a means in obtaining information about foreign customers, foreign employers and employees and their cultures. It helps them understand other cultures better and to reduce potential conflict.

\section{Conclusion and Recommendations}

This research has concerned the roles of foreign language in business administration based on managerial perspectives and the views of co-operative education students. This study showed how foreign language skills are in business administration.

As expected, the answers from different managers in different business sectors to the question about the importance of foreign language were similar. They all said that foreign language was very important to everyone in communicating with others and to working out various issues. Foreign language is important in contacting other countries and foreign customers. The importance of foreign language in business administration depends on the field of business and the nature of the stakeholder it is wished to contact. If the company has been running a tourism business, then it needs to use English very fluently, while for a transportation company involved with foreign travellers, foreign languages certainly play an important role. Having foreign language skills is important for the tourism business and the jewelry store business so that they can serve their foreign customers optimally. The administrators or managers need to speak a foreign language such as English well. This will help create a good first impression in customers because they would be reassured that the company they have chosen to use can understand them well. Having foreign language skills is good. It will help administrators or managers and co-operative education students to reduce obstacles in communication at work by speaking, listening, and writing effectively. Communication with others with understanding is important for the business world. Foreign languages are used to serve and to negotiate with customers and with other foreign companies.

It would be better to know how to communicate with other foreign customers in languages other than English, such as Japanese, Chinese, German or Russian. Customers expect the company they are going to do business with or whose services they will use to be able to understand their language. Those customers will appreciate the language use and will not feel like they are strangers but close to their business partners as people on whom they can rely.

The informants recommended that businesspeople should study Chinese, Japanese, German or Russian as a third language if they wanted to be successful in the business field. Businesspeople should pay more attention to languages for better business administration. The best approach is to identify those countries with which the business is involved and prioritise the relevant language skills. According to the phrase 'language is the bridge to other countries,' then it should be seen that language is a tool for a business to build good relationships with customers in other countries. Negotiation becomes easier if the relationship 
is good and cultural differences are minimised through communication. Foreign language skill helps business flow more efficiently. It may help the company to expand within the country and internationally. In depth understanding of language roles and more specific business or industry issues should be taken in consideration. It is also an important phenomenon in business administration and should be further investigated scientifically.

\section{References}

Adejimola, A. S. (2008). Language, communication and information flow in entrepreneurship. African Journal of Business Management, 2 (x), 201-208.

Barlas, S., Dowsett, C., Verschoor, C., \& Williams, K. (2002). Are you well traveled? Strategic Finance, 83 (10), 19.

Batt, A. (2008). English skills gap is costing Thai businesses. BusinessWeek Thailand, December, 57-58.

Cantoni, G. (1998). The role of cultural factors in the maintenance of indigenous languages. Intercultural Communication Studies, 8 (1), 1-12.

Carroll, J. (2005). What's the importance of learning a foreign language? Business Journal, Retrieved July 27, 2009, from http://riad.bizjournals.com/triad/stories/editorial2.html.

Castro, S. (2006). Understanding representations of English as a foreign language teachers' and students' roles in different contexts in the light of transitivity analysis. Proceedings. $33^{\text {rd }}$ International Systemic Functional Congress 2006, 861-878.

Charvatova, D. (2009). Relationship of knowledge business objectives and effective communication World Academy of Science, Engineering and Technology, 49, 472-477.

Cline, A. (1998). Language, meaning, and communication, the role of language in constructing arguments. Retrieved August 12, 2009, from http://atheism.about.com/od/criticalthinking/a/ language.htm.

Cole, R. E., \& Deskins, D.R. (1988). Racial factors in site location and employment patterns of Japanese auto firms in America. California Management Review, 31 (1), 93-22.

Coleman, M. (2004). Business. Retrieved August 16, 2009, from https://www.crntc.com/images/Business_Insurance_VII.pdf.

Cong, M. (2007). The role of internal communication and training in infusing corporate values and delivering brand promise: Singapore Airlines' experience. Corporate Reputation Review, 10, 201-212.

Cook, J. (2007). Foreign language needs in today's business world. Retrieved July 20, 2009, fromhttp://www.associatedcontent.com/article/222415/foreign_language_needs_in_todays_b usiness.html

Cotton, D., Falvey, D. \& Kent, S. (2007). The keys to successful team building. Market Leader, 71,160 .

Crystal, D. (eds.). (1989). The Cambridge Encyclopedia of Language. Cambridge: Cambridge University Press.

Davies, J. (2000). A Study of language skills in tourism industry. Language Learning Journal, 21 (1), 66-71. 
Dipte, F. N., \& Ali, M. M. (2009). English is now a global business language. Retrieved July 20, 2009, from http://www.thefinancialexpress-bd.com/2009/02/10/58432.html

Ebling, S. (eds). (2005). Why your child should study foreign languages. Learning Beyond, September 2005. Retrieved August 15, 2009, from http://www.achieve-efs.org/ documents/achieve_news_sept05.pdf

Geneva, L. (2002). Language planning in a trans-national speech community. Retrieved August 15, 2009, from http://jan.ucc.nau.edu/ jar/ILAC/

Global Organization Design Society (GO). (2009). A Dependable Path to Exceptional Business Result Based on .... Retrieved August 12, 2009, from http://www.new-management-network.com/pdfs/GO_ReportREV3_05.pdf

Gordon, M.E. (2009). Conversing about performance. Management Communication Quarterly, 22 (3), 473-501.

Griva, E., \& Sivropoulou, R. (2009). Implementation and evaluation of an early foreign language learning project in kindergarten. Early Childhood Educational Journal, 37 (1), 79-87.

Grosse, C. U. (2004). English business communication needs of Mexican executives in a distance-learning class. Business Communication Quarterly, 67 (1), 7-23.

Grunig, E. J., et al. (1992). Excellence in Public Relations and Communication Management. New York: Lawrence Erlbaum.

Hagoort, P., \& Van Berkum, J. (2007). Beyond the sentence given. Philosophical Transactions of the Royal Society, 362, 801-811.

Hulstrand, J. (2008). Becoming proficient in a foreign language is becoming increasingly important to the global workforce in today's 'Flat' world. International Educator, September-October, 24-31.

Friedman, P. J. (1994). Barron's Dictionary of Business Terms. $2^{\text {nd }}$ Edition. New York: Barron's Educational Series.

Iwai, K. (2001). What is corporation: The corporate personality controversy and Comparative Corporate Governance. Retrieved August 14, 2009, from http://www.e.u-tokyo.ac.jp /cirje/research/dp/2001/2001cf100.pdf

Jenkins, O. B. (2000). How to learn a language and a culture. Retrieved August 3, 2009, from http://orvillejenkins.com/langlearn/culturalrole.html

Lechner, A. B. (2008). International Trade: The Future Business. Ohio: South Western.

Leslie, D. \& Russel, H. (2006). The importance of foreign language skills in the tourism sector: A comparative study of student perceptions in the UK and continental Europe. Business School Review, Caledonian University.

Lieberman, A. (2008). Teacher learning: The key to educational reform. Journal of Teacher Education, 59 (3), 226-234.

Marschan-Piekkari, R., Welch, D., \& Welch, L. (1999). In the shadow: The impact of language on structure, power and communication in the multinational. International Business Review, 8 (4), 421-440. 
Marschan, R., Welch, D., \& Welch, L. (1997). Language: The forgotten factor in multinational management. European Management Journal, 15 (5), 591-598.

Mauro, M. (2008). Business services. Retrieved August 15, 2009, from http://www.sos.state.ia.us/business/ sole.html

Mendonca, J. (2003). Model and sample case for teaching business values of information technology. Journal of Information Technology Education, 2 (x), 61-72.

Mittlestands, P. (2007). Knowledge of foreign languages provides more opportunities to SMEs. Retrieved August 3, 2009, from http://www.just4business.eu/2007/ 02/knowledge-of-foreign-languages-provides-more-pportunities-to-smes/

New Zealand Herald, (2007). Language skills open doors. Retrieved August 12, 2009, from http://www.nzalt.org.nz/news/news01.shtml

Peh, C. C. (2005). Challenges, lessons, and opportunities. Retrieved August 12, 2009 http://www.iesingapore.gov.sg/wps/wcm/connect/34f9cd004b6f5422a721a7faddca57e9/IE_T ES_China.pdf?MOD=AJPERES

Pine, K. (2006). Advantages of learning foreign languages. Retrieved August 20, 2009, from http://www.ArticlesTree.com/hobbies/advantages-of-learning-foreign-languages-tx249551.ht $\mathrm{ml}$

Robock, H. S., \& Simmonds, K. (1989). International Business and Multinational Enterprises. $4^{\text {th }}$ Edition. Irwin.

Runnakit, N. (2007). Customers satisfaction with English language communication skills of the front desk staff. Retrieved July 20, 2009, from http://library.utcc.ac.th/onlinethesis/ detail.asp?bib_id=1358

Rasouli, M., Dyke, L., \& Mantler, J. (2008). The role of language and career management self-efficacy on the career adjustment of immigrant women in Canada. The International Journal of Diversity in Organizations, Communities and Nations, 8 (5), 33-42.

Ruffin, N. J. (n. d.). Understanding growth and development patterns of infants. Retrieved July 20, 2009, from http://pubs.ext.vt.edu/350/350-055/350-055.pdf

Samovar, L. A., \& Porter, R. E. (2004). Communication Between Cultures. $5^{\text {th }}$ Edition. Wadsworth/Thomson Learning.

Sanstead, W. G. (2001). Foreign language. Retrieved August 17, 2009, from http://www.dpi.state.nd.us/standard/content/foreign.pdf.

Schorr, L. (2005). A generation of business foreign languages. Retrieved July 27, 2009, from http:// www.mgmt.purdue.edu/centers/ciber/publications/gbl/GBL/Schorr.doc

Schroeder-Saulnier, D. (2009). Organizational effectiveness: Preparing your workforce for change. Retrieved July 27, 2009, from http://www.right.com/capabilities/ organizational-effectiveness/preparing-your-workforce-for-change-a-strategy-for-success.pdf.

Stewart, M. M., \& Others. (1973). Communicating in Your World: Business English and Communication. $5^{\text {th }}$ Edition. Hong Kong: McGraw-Hill.

Stewart, M. M., \& Others. (1985). The Impact of Modern Communication Technology: Business English and Communication. $6^{\text {th }}$ Edition. Singapore: McGraw-Hill. 
Stone, R. (2008). Learning foreign language for international business. Retrieved July 20, 2009, from http://www.learnforeignlanguage.us/easy-foreign-language-learning/learningforeign-language-for-international-business.html

Stoyko, P. (2009). Organizational culture and the management of organizational memory. Retrieved August 14, 2009, from http://www.igi-global.com/downloads/excerpts/ 33147.pdf

Theobald, T., \& Cooper, L.C. (2006). Shut up and listen: The truth about how to communicate at work. London: Kogan Page Limited.

Thill, J., \& Bovee, L.C. (2001). Communication challenges in today's workplace: excellence in business communication. $6^{\text {th }}$ Edition. New York: Pearson Prentice Hall.

Thill, J., \& Bovee, L. C. (2005). Excellence in Business Communication. $6^{\text {th }}$ Edition. New York: Pearson Prentice Hall.

Twells, H. (2008). The importance of foreign language in business. Retrieved July 27, 2009, from http://www.associatedcontent.com/the role of foreign language.html?

Van Berkum, J. (2008). Understanding sentences in context. Association for Psychological Science, 17 (6), 376-380.

Varner, I., \& Beamer, L. (2005). Intercultural Communication in the Global Workplace. $3^{\text {rd }}$ Edition. Hong Kong: McGraw-Hill Irwin.

Voght, G. M., \& Schaub, R. (1992). Foreign languages and international business. Retrieved July 23, 2009, from http://www.cal.org/resources/Digest/voght001.html

Walter, E. (2004). Cambridge Learner's Dictionary. $2^{\text {nd }}$ Edition. Cambridge: Cambridge University Press.

Walters, P.G.P. (1990). The significance of foreign language skills for initial entry positions in international firms. Journal of Teaching in International Business, 1 (3), 71-83. 